\title{
Evaluation of in vitro antagonistic activity of fungi from peatlands against Ganoderma species under acidic condition
}

\author{
SUPRIYANTO ${ }^{1,3, \boldsymbol{\nu}}$, PURWANTO $^{2}$, S.H. POROMARTO ${ }^{2}$, SUPYANI $^{2}$ \\ ${ }^{1}$ Department of Agricultural Science, Graduate School, Universitas Sebelas Maret. Jl. Ir. Sutami 36A, Surakarta 57126, Central Java, Indonesia. \\ Tel./fax.: +62-271-637457, "email: supriyantountan2013@gmail.com \\ ${ }^{2}$ Faculty of Agriculture, Universitas Sebelas Maret. Jl. Ir. Sutami 36A, Surakarta 57126, Central Java, Indonesia. \\ ${ }^{3}$ Department of Agriculture Cultivation, Faculty of Agriculture, Universitas Tanjungpura. Jl. Prof. Dr. H. Hadari Nawawi, Pontianak 78124, \\ West Kalimantan, Indonesia
}

Manuscript received: 26 March 2020. Revision accepted: 8 June 2020

\begin{abstract}
Supriyanto, Purwanto, Poromarto SH, Supyani. 2020. Evaluation of in vitro antagonistic activity of fungi from peatlands against Ganoderma species under acidic conditions. Biodiversitas 21: 2935-2945. The use of peatlands is a significant contributor to the world's palm oil production. A serious problem of oil palm plantations in peatlands is the high incidence of basal stem rot (BSR) disease caused by Ganoderma, which has a higher attack rate than on mineral soils. There is no effective way to control Ganoderma in peatlands. At present, the effort for the same focuses on environment-friendly biological methods; however, this is constrained by the unavailability of appropriate biological agents for peatlands. The development of biological control agents for peatlands is hampered by limited data on biological control of Ganoderma in peatlands. This research was conducted to evaluate the in vitro antagonistic activity of fungi isolated from a peatland in acidic $\mathrm{pH}$ conditions. Twenty-seven Ganoderma-antagonistic fungi from peatland were evaluated for their activity and their ability to antagonism in vitro within a $\mathrm{pH}$ range of 2-7. The results show that most antagonistic fungi from peatland, based on biomass weight, the sporulation ability, and germination of conidium, were able to grow optimally at $\mathrm{pH} 3.0-4.0$, indicating that most of the Ganoderma-antagonistic fungi from peatland can be used as biological control agents for BSR on oil palms in peatlands.
\end{abstract}

Keywords: Acidic pH, biological control, Ganoderma, oil palm, peatland

\section{INTRODUCTION}

The utilization of peatlands is important to global palm oil production. In 2015, the area of oil palm plantation in peatlands in the world was 3.1 million ha. Indonesia, the largest palm oil-producing country in the world, has a large area of oil palm plantations in peatlands, which is 2.046 million ha, equivalent to $14.58 \%$ of the total area of Indonesian palm oil, which until 2017 was 14.03 million ha (Miettinen et al. 2016; Dirjenbun 2017). Most oil palm plantations in peatlands in Indonesia are spread on the islands of Sumatera and Kalimantan. In Kalimantan island, almost half $(42.33 \%)$ of oil palm plantation in peatlands is in the province of West Kalimantan, which covers 309.32 thousand ha (Miettinen et al. 2016).

A serious problem of oil palm plantations in peatlands is the high incidence of basal stem rot (BSR) disease caused by Ganoderma where the attack is higher and appears earlier than in the mineral soils (Azahar et al. 2011; Susanto et al. 2011; Rakib et al. 2017). Economically, Ganoderma attacks are detrimental because they could reduce the yields of crops when the oil palms suffer from BSR diseases by an average of $43.32 \%$ in 6 months (Assis et al. 2016). Ganoderma attacks usually cause palm death, thus shortening the production period. The intensity of BSR disease also always increases with age and oil palm plantation regeneration (Chong et al. 2017). Ganoderma species are saprophytic fungi indigenous tropical rainforest; however, in certain situations it becomes pathogenic (Pilotti 2005; Cooper et al. 2011). In addition, Ganoderma is transmitted through air, besides through root contact, with basidiospores (Rakib et al. 2014), has many host plants (Muniroh et al. 2019), and forms a retaining structure like sclerotium (pseudosclerotia) (Darmono 2000).

There are no effective methods to control the spread of BSR disease in peatlands. Some methods that were developed such as making a mounding at the stem base, "stem surgery" (removing diseased tissue), making isolation trenches, sanitation, land ploughing during oil palm plantation replanting, using fungicides, using cover crop legumes, or oil palm fertilizing improvements. The results of these methods vary greatly (Fee 2011; Wong et al. 2012; Priwiratama et al. 2014; Muniroh et al. 2019). Biological control is an alternative control method that is the focus of current development (Muniroh et al. 2019). However, there are no reports on the biological agents that can be effectively used in peatlands. Its development is constrained by the lack of data on biological control in peatlands, which have different characteristics compared to mineral soils. The characteristic of tropical peatlands which is considered a serious obstacle in biological control is its extremely low $\mathrm{pH}$ level. Tropical peatlands in the lowlands of Kalimantan have an average $\mathrm{pH}$ of 3.3 for the deepest peatland, whereas shallow peatlands have an average $\mathrm{pH}$ of 4.3 (Andriesse 1988). 
Various Trichoderma species are known to be the main antagonists of Ganoderma (Naher et al. 2015; Alexander et al. 2017; Musa et al. 2018). The $\mathrm{pH}$ value of the growing medium was reported as the most important parameter that influences the growth and sporulation of Trichoderma because it determines the availability of minerals and influences the metabolic rate and enzymatic activity (Zehra et al. 2017). Acidic soil conditions usually increase spore germination, conidiophore production, mycelial growth, antibiotic production, and reduce the fungus conidium fungistatic (Bakker et al. 2012). However, evaluation of the activity and dynamics of the antagonistic capabilities of various Ganoderma antagonists in low $\mathrm{pH}$ environments has not been widely reported. This research aims to determine the fungal biomass growth, sporulation, and germination of the conidia of Ganoderma-antagonistic fungi from peatlands and their antagonism ability in the low $\mathrm{pH}$ range. This information is important in the development of strategies for controlling the BSR disease of oil palm in peatlands caused by the Ganoderma species.

\section{MATERIALS AND METHODS}

The origin of Ganoderma isolates and their antagonists

Ganoderma isolates were isolated from Ganoderma fruit bodies taken from diseased oil palms at PT. Bumi Pratama Khatulistiwa (PT. BPK) in Kubu Raya District, West Kalimantan Province, Indonesia $\left(0^{\circ} 2^{\prime} 44.11^{\prime \prime} \mathrm{N}\right.$, $\left.109^{\circ} 26^{\prime} 6.20^{\prime \prime} \mathrm{E}\right)$. The Ganoderma-antagonistic fungal isolates were collected from peat soils of 10 sample blocks in PT. BPK (Figure 1). Three samples were taken from each block at depths of $0-15 \mathrm{~cm}$ and $50-60 \mathrm{~cm}$. The samples from each block were made into a composite based on a depth of $0-15 \mathrm{~cm}$ as a layer, which was routinely disturbed by land maintenance activities, and a depth of $50-60 \mathrm{~cm}$ as a layer that is considered to be minimally disturbed during land maintenance. The $\mathrm{pH}$ value of each peat sample was measured by mixing $2.5 \mathrm{~mL}$ of fresh peat with $4 \mathrm{~mL}$ of $0.01 \mathrm{M} \mathrm{CaCl}_{2}$ solution and allowed to stand for at least an hour and the $\mathrm{pH}$ was measured (Notohadiprawiro 1985).

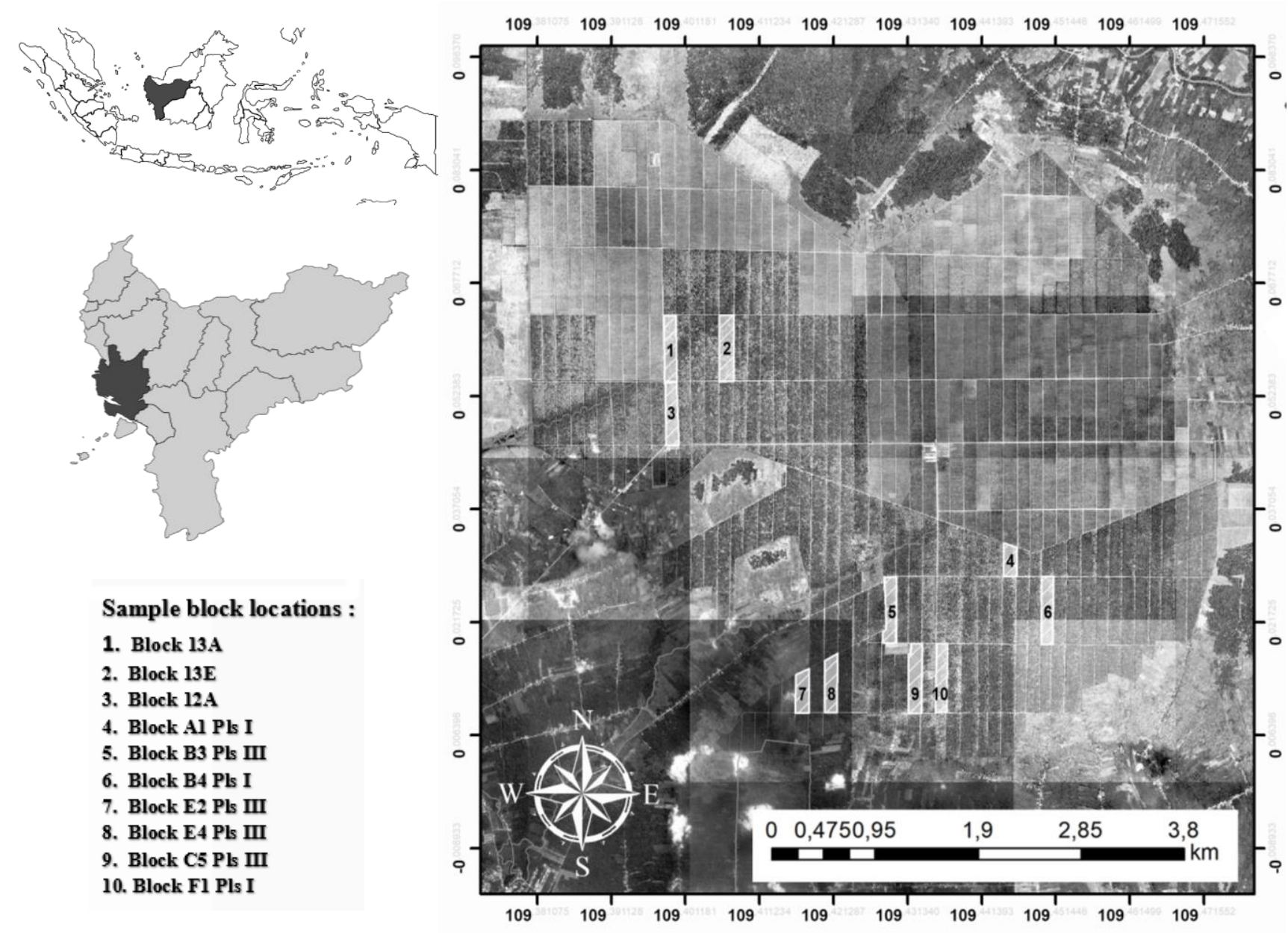

Figure 1. Map of the peat soil sampling locations in Kubu Raya District, West Kalimantan Province, Indonesia 
Measurements of peat $\mathrm{pH}$ were carried out in three replications. Isolation was carried out by serial dilution on potato-dextrose agar (PDA) and Martin agar medium, identified based on colony morphological characteristics and characteristics of conidiophores and conidia (Domsch and Gams 1972). The isolated fungi were tested for their antagonistic ability against Ganoderma by dual culture method. Disc-shaped pieces of antagonistic candidate isolates and 3-day old Ganoderma isolates of 5-mm diameter were placed opposite at a distance of $4 \mathrm{~cm}$ in a petri dish, incubated at room temperature, and were observed for 7 days. The percentage of inhibition of antagonistic fungi against Ganoderma was calculated by the formula $(100 \times(\mathrm{CT}) / \mathrm{C})$, where $\mathrm{C}$ is the radius of the Ganoderma mycelium leading to the petri dish edge and $\mathrm{T}$ is the Ganoderma radius leading to the antagonist (Ahlem et al. 2012; Ting and Jioe 2016). Isolates with inhibition of $\geq 60 \%$ were maintained in a PDA medium at $\mathrm{pH} 5.5$ for further testing. PDA $\mathrm{pH} 5.5$ was obtained by adding $\mathrm{HCl}$ and measuring until it reached $\mathrm{pH} 5.5$ before the medium was autoclaved.

\section{The effect of $\mathrm{pH}$ degrees on antagonistic fungal biomass growth in potato-dextrose broth (PDB)}

PDB (HiMedia) was dissolved in distilled water and

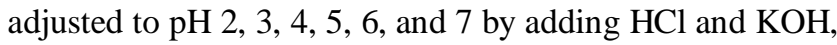
according to the required $\mathrm{pH}$ adjustment. A total of $20 \mathrm{~mL}$ of PDB was placed into a $100 \mathrm{~mL}$ bottle and autoclaved for 15 minutes at $121^{\circ} \mathrm{C}$. After it cooled down, a 5-mm diameter of 3-day old antagonistic fungal isolate disc was inoculated and shaken at $150 \mathrm{rpm}$ for 7 days. On the $7^{\text {th }}$ day, culture was harvested by filtering, using Whatman No. 1 filter paper that had previously been stored in an oven at $80^{\circ} \mathrm{C}$ for 24 hours and weighed. The filtering results substrates were then dried in an oven at $80^{\circ} \mathrm{C}$ and weighed every 24 hours until their weight was relatively constant. The final weight of biomass was calculated by subtracting the weight of the dry substrates with the initial filter-paper weight (Senthamizhlselvan et al. 2010).

\section{The effect of $\mathrm{pH}$ degrees on sporulation and mycelial biomass growth in PDA}

The testing of the effect of $\mathrm{pH}$ on sporulation and growth of mycelium biomass was carried out following the method of Senthamizhlselvan et al. (2010) with modification. PDB was dissolved at $2 \times$ concentration in McIlvaine buffer (McIlvaine 1921) at pH 2, 3, 4, 5, 6, and 7 , and then adjusted by adding $\mathrm{HCl}$ and $\mathrm{KOH}$, according to the required $\mathrm{pH}$ adjustment (Steyaert et al. 2010). An equivalent volume of water agar was prepared at $2 \times$ concentration and then both were sterilized. Both solutions were then combined immediately before pouring into 10$\mathrm{cm}$ Petri dishes. After it cooled down, antagonistic isolates with a 5-mm diameter and aged 3 days were inoculated in the middle of a petri dish and incubated for 7 days. The growth of the colony diameter was observed every day. On the $7^{\text {th }}$ day, conidium and mycelium were harvested. The conidium was harvested by adding $10 \mathrm{~mL}$ of sterile distilled water to the culture and the conidia were slowly scraped off. The conidium was then filtered using sterile cheesecloth. The amount of conidium was calculated using a hemocytometer by observing the number of conidia in the smallest plot under a light microscope at 400x magnification. Mycelium biomass was harvested by melting the agar culture that was previously added to 10 $\mathrm{mL}$ of $0.1 \mathrm{~N} \mathrm{HCl}$ in a water bath at $90^{\circ} \mathrm{C}$. The mycelium was then filtered using Whatman No.1 filter paper, which was previously stored in an oven at $80^{\circ} \mathrm{C}$ for 24 hours and weighed. Mycelium was then dried in an oven at $80^{\circ} \mathrm{C}$ and weighed every 24 hours until their weight was relatively constant. The weight of mycelium was calculated by subtracting the weight of the dry mycelium with the initial filter-paper weight.

\section{The effect of $\mathrm{pH}$ degrees on conidia germination}

Conidium was harvested from 3-day old antagonistic isolate culture by adding $10 \mathrm{~mL}$ sterile distilled water and then the conidium was filtered using sterile cheesecloth, following which $0.1-\mathrm{mL}$ conidium suspension was placed on a thin layer of water agar media and their $\mathrm{pH}$ was adjusted using McIlvaine buffer (Mc Ilvaine 1921) at $\mathrm{pH} 2$, $3,4,5,6$, and 7, and incubated at room temperature. After 24 hours, the conidium was stained with lactophenol cotton blue, and the number of germinated conidia was observed under a light microscope at $400 \times$ magnification.

\section{The effect of pH degrees on the antagonistic ability against Ganoderma}

For each antagonistic fungi species obtained in antagonism screening tests, one representative sample of isolates was taken randomly to test its ability as a Ganoderma antagonist in low $\mathrm{pH}$. The effect of the degree of $\mathrm{pH}$ on the ability of antagonism was observed by the dual culture method between antagonistic isolates and Ganoderma on a PDA medium that was prepared at $\mathrm{pH} 2$, 3, 4, 5, 6, and 7, using a McIlvaine buffer (McIlvaine 1921). Disc-shaped pieces of Ganoderma-antagonistic isolates and 3-day old Ganoderma isolates $5 \mathrm{~mm}$ in diameter were placed opposite at a distance of $4 \mathrm{~cm}$ on a PDA medium in a petri dish, incubated at room temperature and observed for 7 days. The percentage of inhibition of antagonistic fungi against Ganoderma was calculated by the formula $(100 \times(\mathrm{CT}) / \mathrm{C})$, where $\mathrm{C}$ is the radius of the Ganoderma mycelium leading to the Petri dish edge and $\mathrm{T}$ is the Ganoderma radius that leads to the antagonist (Ahlem et al. 2012).

\section{RESULTS AND DISCUSSION}

\section{The antagonistic isolates origin environment}

Out of the peat soils taken from 10 blocks of the observed samples, 27 fungal isolates were obtained that had the ability of Ganoderma antagonists, consisting of four fungi isolates from the Gliocladium genera and 23 from the Trichoderma genera. As reported by Supriyanto et al. (2020), these 10 samples of oil palm plantation blocks in the peatlands were the ones attacked by Ganoderma with varying intensities, ranging from $4.62 \%$ to $69.81 \%$. Candidates for the Ganoderma-antagonist fungi were taken from the infected area because peatland characteristics 
were varied across different locations. Thus, if the Ganoderma-antagonist fungi were taken from another area, there is a possibility that it would not be suitable for use in these locations. Three blocks, namely 12A, 13A, and 13E, were intensively maintained with twice-a-year fertilization, including NPK, Borate, and $\mathrm{CuSO}_{4}$ fertilizers. Meanwhile, 7 other blocks were maintained intensively until the age of around 8 years; however, the maintenance was less intensive subsequently. The $\mathrm{pH}$ degrees of peatlands ranged from 2.2 to 3.4 (Table 1 ).

\section{The effect of low pH degrees on the growth of antagonistic fungal mycelium}

Based on the dry weight of mycelium (mycelium biomass), there are variations in the growth of antagonistic fungal isolates due to media $\mathrm{pH}$ treatment, both in PDB and PDA. In PDB medium wherein the $\mathrm{pH}$ was adjusted from 2 to 7 , there were $77.8 \%$ antagonistic fungal isolates showing growth response patterns as convex curves. The response patterns of 4 isolates (12AJ4, 12AJ7, F1J24, and 13EJ35) were like sigmoid curves and 2 isolates (13AJ10 and E4J11) were similar to concave curves. 37\% isolates reached a maximum of mycelium biomass at $\mathrm{pH} \mathrm{3,37 \%}$ isolates at $\mathrm{pH} 4$, and $26 \%$ isolates at $\mathrm{pH} 5$ and $\mathrm{pH} 6$ (Table 2). Meanwhile, in the PDA medium, there were $41 \%$ isolates whose maximum biomass reached $\mathrm{pH} \mathrm{4,} \mathrm{pH} 3$, and $\mathrm{pH} \mathrm{2,} \mathrm{and} \mathrm{the} \mathrm{other} \mathrm{isolates} \mathrm{reached} \mathrm{pH} 5$ (25.9\%) and $\mathrm{pH} 6$ and $\mathrm{pH} 7$ (33.3\%) (Table 2 and 3). The results also showed that in the PDB medium, 74\% isolates had maximum growth at $\mathrm{pH} 3$ and $\mathrm{pH} 4$, whereas on PDA medium, only $67 \%$ of isolates were able to grow at acidic $\mathrm{pH}(\mathrm{pH} 4,3$, and 2). Except for B3J19, 13EJ15, E4J8, 12AJ7, and E4J13 isolates, all isolates produced maximum biomass at lower $\mathrm{pH}$ in the PDB medium than in PDA medium. This is probably because, in a liquid medium, the fungal mycelium is believed to be freely dispersed evenly throughout the medium and form macroscopic aggregates (Veiter et al. 2018). Therefore, absorption of nutrients and oxygen occurs faster (Zhou et al. 2018). Meanwhile, in a solid medium, fungal mycelium can only grow on the surface of the medium (Canovas et al. 2017; Gomes et al. 2018).

The results of the analysis of variance of the mycelium biomass with a confidence level of $95 \%$ also showed that there were significant differences among the isolates in response to changes in the $\mathrm{pH}$ degrees of $\mathrm{PDB}$ and PDA medium. Five isolates' biomass was significantly different from other isolates in the $\mathrm{pH} 2 \mathrm{PDB}$ medium; these were B3J19, B3J9, 13EJ15, 13AJ6, and 12AJ7. At the same pH, 8 isolates, 13AJI0, C5J16, E4J8, E4J11, 13EJ15, B4J28, B3J19, and F1J6, in PDA had higher biomass than in PDB. Growth variation among the isolates was also observed in antagonistic fungal colony diameter on PDA medium, where a greater growth variation was found at $\mathrm{pH} 2,6$, and 7, as compared to $\mathrm{pH} 3,4$, and 5. Most isolates had an ideal range of mycelium growth at $\mathrm{pH} 3$ to $\mathrm{pH} 5$ (Figure 2).

Table 1. Peatland $\mathrm{pH}$ degrees of Ganoderma-antagonistic fungi origin that were tested in this research

\begin{tabular}{|c|c|c|c|c|c|}
\hline \multirow[b]{2}{*}{ Isolate code } & \multirow[b]{2}{*}{ Species } & \multirow{2}{*}{$\begin{array}{c}\text { Inhibition against } \\
\text { Ganoderma }(\%)\end{array}$} & \multirow[b]{2}{*}{ Blocks } & \multicolumn{2}{|c|}{ Peat pH $\left(\mathrm{CaCl}_{2}\right)$} \\
\hline & & & & $\begin{array}{c}\text { At depth } \\
0-15 \mathrm{~cm}\end{array}$ & $\begin{array}{l}\text { At depth } \\
50-60 \mathrm{~cm}\end{array}$ \\
\hline $12 \mathrm{AJ} 4$ & Trichoderma harzianum & 76.0 & $12 \mathrm{~A}$ & 2.4 & - \\
\hline $12 \mathrm{AJ} 7$ & Trichoderma harzianum & 70.0 & $12 \mathrm{~A}$ & 2.4 & - \\
\hline $13 \mathrm{AJ} 10$ & Trichoderma harzianum & 72.7 & $13 \mathrm{~A}$ & - & 2.3 \\
\hline $13 \mathrm{AJ} 4$ & Gliocladium viride & 76.9 & $13 \mathrm{~A}$ & 2.9 & - \\
\hline $13 \mathrm{AJ} 6$ & Trichoderma harzianum & 71.4 & $13 \mathrm{~A}$ & 2.9 & - \\
\hline $13 \mathrm{EJ} 4 \mathrm{~A}$ & Gliocladium viride & 75.0 & $13 \mathrm{E}$ & 2.9 & - \\
\hline $13 \mathrm{EJ} 15$ & Trichoderma harzianum & 730 & $13 \mathrm{E}$ & - & 2.4 \\
\hline $13 \mathrm{EJ} 35$ & Trichoderma harzianum & 80.0 & $13 \mathrm{E}$ & - & 2.4 \\
\hline $13 \mathrm{EJ} 4$ & Gliocladium sp. & 80.95 & $13 \mathrm{E}$ & 2.9 & - \\
\hline $13 \mathrm{EJ} 8$ & Trichoderma harzianum & 75.0 & $13 \mathrm{E}$ & 2.9 & - \\
\hline B3J19 & Trichoderma viride & 70.0 & B3 Pls III & 3.1 & - \\
\hline $\mathrm{B} 3 \mathrm{~J} 3$ & Trichoderma harzianum & 80.0 & B3 Pls III & 3.1 & - \\
\hline B3J5 & Trichoderma harzianum & 80.0 & B3 Pls III & 3.1 & - \\
\hline B3J9 & Trichoderma harzianum & 70.0 & B3 Pls III & 3.1 & _ \\
\hline B4J20 & Trichoderma viride & 70.0 & B4 Pls I & 3.0 & - \\
\hline $\mathrm{B} 4 \mathrm{~J} 28$ & Trichoderma harzianum & 83.0 & B4 Pls I & 3.0 & - \\
\hline B4J9 & Trichoderma viride & 80.0 & B4 Pls I & - & 2.6 \\
\hline $\mathrm{C} 5 \mathrm{~J} 10$ & Trichoderma harzianum & 75.0 & C5 Pls III & 3.4 & - \\
\hline $\mathrm{C} 5 \mathrm{~J} 12$ & Trichoderma harzianum & 77.0 & C5 Pls III & 3.4 & - \\
\hline C5J16 & Trichoderma harzianum & 100.0 & C5 Pls III & 3.4 & - \\
\hline $\mathrm{C} 5 \mathrm{~J} 18$ & Trichoderma harzianum & 68.0 & C5 Pls III & 3.4 & - \\
\hline E4J11 & Trichoderma harzianum & 76.0 & E4 Pls III & - & 2.8 \\
\hline $\mathrm{E} 4 \mathrm{~J} 13$ & Trichoderma harzianum & 76.0 & E4 Pls III & 3.3 & - \\
\hline E4J8 & Trichoderma harzianum & 85.0 & E4 Pls III & 3.3 & - \\
\hline $\mathrm{F} 1 \mathrm{~J} 24$ & Trichoderma harzianum & 70.0 & F1 Pls I & 2.6 & - \\
\hline F1J4 & Trichoderma harzianum & 75 & F1 Pls I & - & 2.3 \\
\hline F1J6 & Gliocladium viride & 65.0 & F1 Pls I & 2.6 & - \\
\hline
\end{tabular}


Table 2. Dry weight of mycelium variation of Ganoderma-antagonistic fungi isolates grown in PDB medium in the $\mathrm{pH}$ range 2-7 for 7 days

\begin{tabular}{|c|c|c|c|c|c|c|c|}
\hline \multirow{2}{*}{$\begin{array}{l}\text { Isolate } \\
\text { code }\end{array}$} & \multirow{2}{*}{ Species } & \multicolumn{6}{|c|}{ Dry weigh of mycelium (mg) } \\
\hline & & pH 2 & pH 3 & pH 4 & pH 5 & pH 6 & pH 7 \\
\hline $12 \mathrm{AJ} 4$ & T. harzianum & $6.6 \mathrm{ab}$ & $82.2 \mathrm{a}$ & $97.8 \mathrm{i}$ & $76.7 a$ & $72.2 \mathrm{ghi}$ & $75.6 \mathrm{def}$ \\
\hline $12 \mathrm{AJ} 7$ & T. harzianum & $13.2 b c$ & $81.1 \mathrm{a}$ & $62.2 \mathrm{cdef}$ & $77.8 \mathrm{a}$ & $93.3 \mathrm{i}$ & $92.2 \mathrm{f}$ \\
\hline $13 \mathrm{AJ} 10$ & T. harzianum & 7.0ab & $73.3 \mathrm{a}$ & 70.0cdefgh & $4.4 \mathrm{a}$ & $5.6 \mathrm{a}$ & $25.6 a b$ \\
\hline $13 \mathrm{AJ} 4$ & G. viride & $4.2 \mathrm{a}$ & $91.1 \mathrm{a}$ & 85.6fghi & $55.8 \mathrm{a}$ & $92.2 \mathrm{i}$ & 74.4def \\
\hline 13EJ4A & T. harzianum & $8.2 \mathrm{ab}$ & $71.7 \mathrm{a}$ & 71.7cdefgh & $47.5 \mathrm{a}$ & 64.2efgh & $65.8 \mathrm{cdef}$ \\
\hline $13 \mathrm{AJ} 6$ & G. viride & $15.4 \mathrm{c}$ & $116.7 \mathrm{a}$ & 76.7cdefghi & $78.9 \mathrm{a}$ & $72.2 \mathrm{ghi}$ & 61.1cdef \\
\hline 13EJ15 & T. harzianum & $23.2 \mathrm{~d}$ & $82.2 \mathrm{a}$ & 80.0efghi & $67.8 \mathrm{a}$ & 68.9fghi & 74.4def \\
\hline 13EJ35 & T. harzianum & $3.9 \mathrm{a}$ & $56.7 \mathrm{a}$ & $36.7 \mathrm{ab}$ & $42.2 \mathrm{a}$ & 41.1bcde & 56.7 bcde \\
\hline $13 \mathrm{EJ} 4$ & Gliocladium sp. & $5.3 \mathrm{a}$ & $64.2 \mathrm{a}$ & 57.5 bcde & $93.3 \mathrm{a}$ & $50.8 \mathrm{cdefg}$ & $60.8 \mathrm{cdef}$ \\
\hline $13 \mathrm{EJ} 8$ & T. harzianum & $5.2 \mathrm{a}$ & $64.2 \mathrm{a}$ & 58.3 bcde & $54.2 \mathrm{a}$ & $58.3 \mathrm{efgh}$ & 49.2bcde \\
\hline B3J19 & T. viride & $32.2 \mathrm{e}$ & $32.2 \mathrm{a}$ & $55.6 \mathrm{bcd}$ & $58.9 \mathrm{a}$ & 53.3cdefg & 61.1cdef \\
\hline B3J3 & T. harzianum & $3.7 \mathrm{a}$ & $56.7 \mathrm{a}$ & 73.3cdefgh & $43.3 \mathrm{a}$ & $31.1 \mathrm{bcd}$ & $8.9 \mathrm{a}$ \\
\hline B3J5 & T. harzianum & $1.2 \mathrm{a}$ & $94.4 \mathrm{a}$ & $54.4 \mathrm{abc}$ & $38.9 \mathrm{a}$ & $24.4 \mathrm{ab}$ & $31.1 \mathrm{abc}$ \\
\hline B3J9 & T. harzianum & $26.2 \mathrm{de}$ & $81.1 \mathrm{a}$ & 83.3fghi & $83.3 \mathrm{a}$ & $52.2 \mathrm{cdefg}$ & $64.4 \mathrm{cdef}$ \\
\hline $\mathrm{B} 4 \mathrm{~J} 20$ & T. viride & $3.3 \mathrm{a}$ & $67.5 \mathrm{a}$ & $87.5 \mathrm{ghi}$ & $75.8 \mathrm{a}$ & 65.0efgh & 61.7cdef \\
\hline $\mathrm{B} 4 \mathrm{~J} 28$ & T. harzianum & $1.8 \mathrm{a}$ & $121.7 \mathrm{a}$ & 75.0cdefghi & $809.2 b$ & $74.2 \mathrm{ghi}$ & $70.8 \mathrm{def}$ \\
\hline B4J9 & T. viride & $2.0 \mathrm{a}$ & $106.7 \mathrm{a}$ & $54.4 \mathrm{abc}$ & $17.8 \mathrm{a}$ & $24.4 \mathrm{ab}$ & $60.0 \mathrm{cdef}$ \\
\hline $\mathrm{C} 5 \mathrm{~J} 10$ & T. harzianum & $4.0 \mathrm{a}$ & $73.3 \mathrm{a}$ & 65.0cdefg & $78.3 \mathrm{a}$ & 66.1efgh & $78.3 \mathrm{ef}$ \\
\hline $\mathrm{C} 5 \mathrm{~J} 12$ & T. harzianum & $4.5 \mathrm{a}$ & $66.7 \mathrm{a}$ & 67.8 cdefgh & $44.4 \mathrm{a}$ & 62.2efgh & 53.3bcde \\
\hline $\mathrm{C} 5 \mathrm{~J} 16$ & T. harzianum & $8.2 \mathrm{ab}$ & $112.0 \mathrm{a}$ & $90.0 \mathrm{hi}$ & $85.3 \mathrm{a}$ & $82.7 \mathrm{hi}$ & 78.0ef \\
\hline C5J18 & $T$, harzianum & $2.5 \mathrm{a}$ & $389.3 b$ & $551.3 \mathrm{j}$ & $566.7 \mathrm{~b}$ & $564.0 \mathrm{j}$ & $559.3 \mathrm{~g}$ \\
\hline $\mathrm{E} 4 \mathrm{~J} 11$ & T. harzianum & $2.2 \mathrm{a}$ & $55.0 \mathrm{a}$ & $53.3 \mathrm{abc}$ & $70.0 \mathrm{a}$ & 65.0efgh & 56.7bcde \\
\hline $\mathrm{E} 4 \mathrm{~J} 13$ & T. harzianum & $3.3 \mathrm{a}$ & $31.7 \mathrm{a}$ & $33.3 \mathrm{a}$ & $30.8 \mathrm{a}$ & 55.8defg & $40.8 \mathrm{bcd}$ \\
\hline $\mathrm{E} 4 \mathrm{~J} 8$ & T. harzianum & $5.6 \mathrm{a}$ & $72.2 \mathrm{a}$ & 78.9defghi & $64.4 \mathrm{a}$ & $57.8 \mathrm{efgh}$ & 46.7bcde \\
\hline $\mathrm{F} 1 \mathrm{~J} 24$ & T. harzianum & $4.9 \mathrm{a}$ & $67.8 \mathrm{a}$ & 80.0efghi & $50.0 \mathrm{a}$ & $57.8 \mathrm{efgh}$ & $77.8 \mathrm{ef}$ \\
\hline $\mathrm{F} 1 \mathrm{~J} 4$ & T. harzianum & $0.4 \mathrm{a}$ & $64.4 \mathrm{a}$ & 57.8 bcde & $102.2 \mathrm{a}$ & 44.4bcdef & $71.1 \mathrm{def}$ \\
\hline F1J6 & G. viride & $3.3 \mathrm{a}$ & $46.7 \mathrm{a}$ & 67.8 cdefgh & $43.3 \mathrm{a}$ & $28.9 \mathrm{abc}$ & 43.3bcde \\
\hline
\end{tabular}

Note: Means followed by the same letters were not significantly different at $5 \%$ level of significant

Table 3. Dry weight of mycelium of Ganoderma-antagonistic fungi isolates from peatlands grown in PDA medium in the $\mathrm{pH}$ range 2-7 for 7 days

\begin{tabular}{|c|c|c|c|c|c|c|c|}
\hline \multirow{2}{*}{ Isolate } & \multirow{2}{*}{ Species } & \multicolumn{6}{|c|}{ Dry weigh of mycelium (mg) } \\
\hline & & pH 2 & pH 3 & pH 4 & pH 5 & pH 6 & pH 7 \\
\hline $12 \mathrm{AJ} 4$ & T. harzianum & $27.8 \mathrm{abc}$ & $36.7 \mathrm{abc}$ & 61.1bcdef & 51.1abcde & $65.6 \mathrm{cdefgh}$ & 77.8efghij \\
\hline $12 \mathrm{AJ} 7$ & T. harzianum & 46.7cdefgh & 70.0defgh & $56.7 \mathrm{bcdef}$ & 53.3abcde & 53.3bcdef & $56.7 \mathrm{cdefg}$ \\
\hline $13 \mathrm{AJ} 10$ & T. harzianum & 57.5defghi & $39.2 \mathrm{abc}$ & $35.0 \mathrm{ab}$ & 61.7bcdef & 70.0efgh & $94.2 \mathrm{hij}$ \\
\hline $13 \mathrm{AJ} 4$ & G. viride & $0,0 \mathrm{a}$ & $22.2 \mathrm{a}$ & $41.1 \mathrm{ab}$ & $35.6 \mathrm{ab}$ & 63.3bcdefgh & 52.2 bcdef \\
\hline 13EJ4A & T. harzianum & 51.1cdefghi & 85.6ghi & 87.8fgh & 105.6hi & $35.6 \mathrm{ab}$ & 61.1cdefgh \\
\hline $13 \mathrm{AJ} 6$ & G. viride & 47.8 cdefgh & $73.3 \mathrm{efgh}$ & $93.3 \mathrm{gh}$ & $66.7 \mathrm{cdef}$ & $111.1 \mathrm{j}$ & $43.3 \mathrm{bcd}$ \\
\hline $13 \mathrm{EJ} 15$ & T. harzianum & $68.9 \mathrm{ghi}$ & 58.3bcdefgh & 65.0bcdefg & 41.7abc & 38.3abc & 53.3bcdef \\
\hline $13 \mathrm{EJ} 35$ & T. harzianum & $28.9 \mathrm{bcd}$ & $28.1 \mathrm{ab}$ & $36.7 \mathrm{ab}$ & 48.3abcd & 48.0abcde & 51.3bcdef \\
\hline $13 \mathrm{EJ} 4$ & Gliocladium sp. & 46.7cdefgh & 86.7 ghi & 80.8efgh & 109.2hi & 88.3ghij & $107.5 \mathrm{j}$ \\
\hline $13 \mathrm{EJ} 8$ & T. harzianum & $0,0 \mathrm{a}$ & 75.6fghi & 65.6bcdefg & 54.4abcdef & 56.7bcdef & $48.9 \mathrm{bcde}$ \\
\hline B3J19 & T. viride & $78.9 \mathrm{i}$ & $34.4 \mathrm{abc}$ & $47.8 \mathrm{abc}$ & 54.4abcdef & $38.9 \mathrm{abc}$ & 63.3cdefghi \\
\hline B3J3 & T. harzianum & $30.0 \mathrm{bcde}$ & 42.2abcd & 48.9abcd & $26.7 \mathrm{a}$ & 43.3abcde & $37.8 \mathrm{abcd}$ \\
\hline B3J5 & T. harzianum & 48.3cdefgh & $32.5 \mathrm{abc}$ & 63.5bcdefg & 80.8efgh & $100.8 \mathrm{ij}$ & $95.8 \mathrm{ij}$ \\
\hline B3J9 & T. harzianum & 44.4cdefgh & 44.4abcde & $56.7 \mathrm{bcdef}$ & 58.9bcdef & 50.0 bcdef & $35.6 \mathrm{abc}$ \\
\hline B4J20 & T. viride & $37.3 \mathrm{cdef}$ & 51.3abcdef & 46.0abc & $122.0 \mathrm{i}$ & 78.0fghi & $40.7 \mathrm{bcd}$ \\
\hline B4J28 & T. harzianum & 71.1hi & 77.5fghi & 46.7abc & 60.8 bcdef & $55.8 \mathrm{bcdef}$ & $42.5 \mathrm{bcd}$ \\
\hline B4J9 & T. viride & $8.9 \mathrm{ab}$ & $35.6 a b c$ & $36.7 \mathrm{ab}$ & $67.8 \mathrm{cdef}$ & 61.1bcdefg & 66.7cdefghi \\
\hline C5J10 & T. harzianum & 40.0cdefg & $35.8 \mathrm{abc}$ & $37.5 \mathrm{ab}$ & $30.8 \mathrm{ab}$ & $40.8 \mathrm{abcd}$ & $5.8 \mathrm{a}$ \\
\hline C5J12 & T. harzianum & $26.7 \mathrm{abc}$ & $87.8 \mathrm{hi}$ & 80.0defgh & $123.3 \mathrm{i}$ & $162.2 \mathrm{k}$ & 84.4fghij \\
\hline C5J16 & T. harzianum & 58.9efghi & 56.7bcdefg & $96.7 \mathrm{~h}$ & $167.8 \mathrm{j}$ & $106.7 \mathrm{j}$ & 87.8ghij \\
\hline C5J18 & $T$, harzianum & 50.8cdefghi & $62.5 \mathrm{cdefgh}$ & 50.8abcde & 70.0 cdefg & 77.5fghi & $20.0 \mathrm{ab}$ \\
\hline E4J11 & T. harzianum & 64.4fghi & $62.2 \mathrm{cdefgh}$ & $20.0 \mathrm{a}$ & 56.7abcdef & 61.1bcdefg & 71.1defghi \\
\hline E4J13 & T. harzianum & 44.4cdefgh & $103.3 \mathrm{i}$ & 82.5efgh & $97.5 \mathrm{ghi}$ & 69.2defgh & 80.8efghij \\
\hline E4J8 & T. harzianum & 60.7 fghi & 48.7abcdef & $40.0 \mathrm{ab}$ & 48.7abcd & $20.7 \mathrm{a}$ & $34.0 \mathrm{abc}$ \\
\hline $\mathrm{F} 1 \mathrm{~J} 24$ & T. harzianum & $25.6 \mathrm{abc}$ & 43.3abcde & $56.7 \mathrm{bcdef}$ & 41.1abc & 47.8abcde & $54.4 \mathrm{cdefg}$ \\
\hline $\mathrm{F} 1 \mathrm{~J} 4$ & T. harzianum & 47.5cdefgh & 70.8defgh & 75.8cdefgh & 75.8defg & 90.0hij & 53.3bcdef \\
\hline F1J6 & G. viride & $79.2 \mathrm{i}$ & 52.5abcdef & $41.7 \mathrm{ab}$ & $85.0 \mathrm{fgh}$ & $35.8 \mathrm{ab}$ & 83.3efghij \\
\hline
\end{tabular}

Note: Means followed by the same letters were not significantly different at $5 \%$ level of significance 

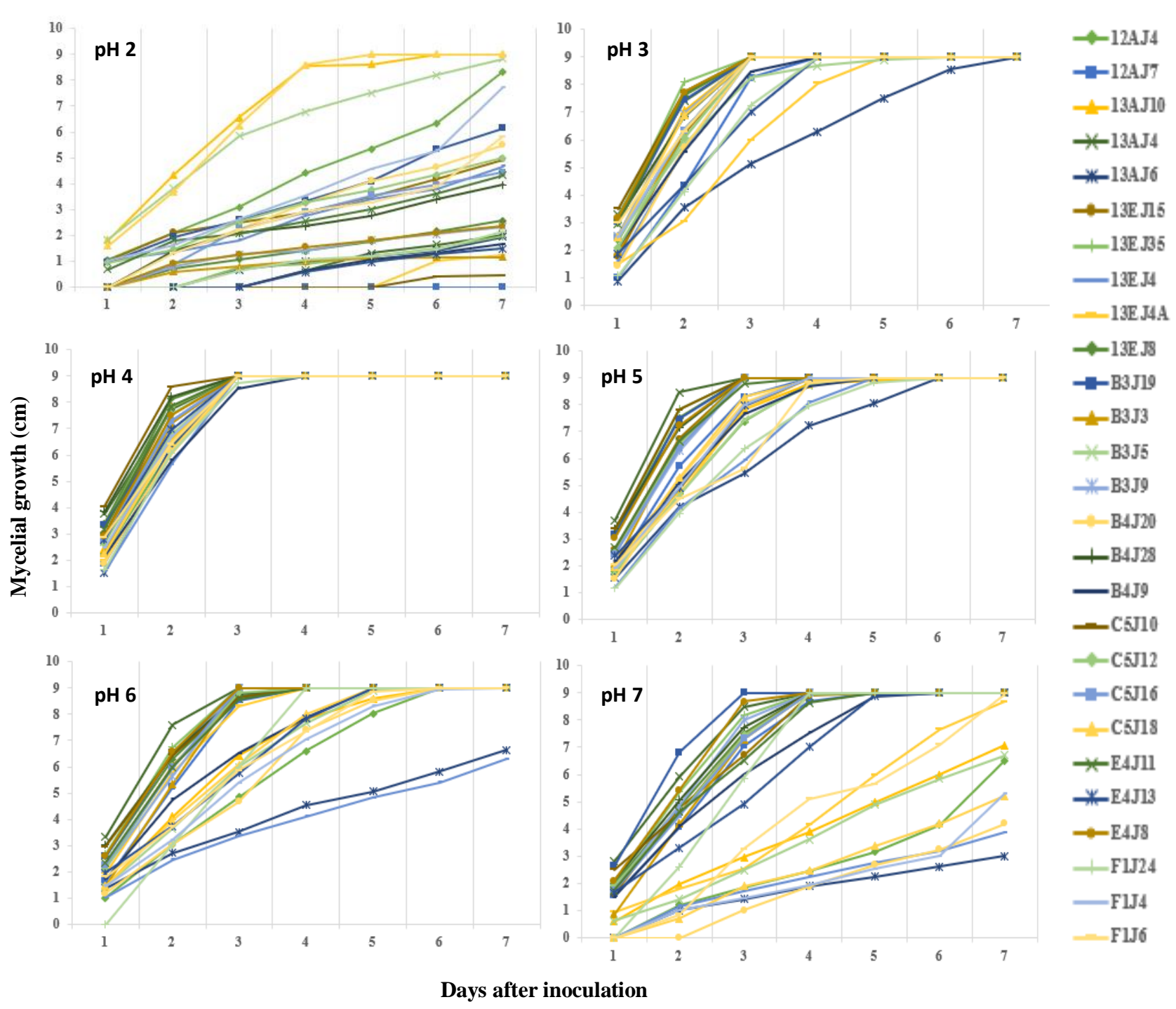

Figure 2. Patterns of the mycelial growth response of 27 isolates of Ganoderma-antagonistic fungi from peatlands grown in PDA medium with a $\mathrm{pH}$ of 2-7 for 7 days of observation

Variations in the growth of mycelium isolate from Ganoderma-antagonists from peatlands at low $\mathrm{pH}$ degrees occur at the species level. In the PDB medium, all Gliocladium viride isolates were weak at $\mathrm{pH} 2$. However, except for the 13AJ4 isolate, all others could produce

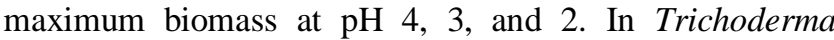
harzianum, only 3 isolates were able to produce significantly higher biomass at $\mathrm{pH} 2$, namely 13EJ15, B3J9, and 13AJ6 isolates. Most of the isolates could also produce maximum

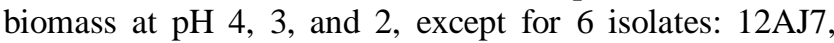
B3J9, C5H10, E4J13, E4J11, and F1J4. Meanwhile, in Trichoderma viride, only one isolate, namely B3J19, could grow to $\mathrm{pH} 2$. However, all $T$. viride isolates were able to produce maximum biomass at $\mathrm{pH} 4,3$, and 2 .

In the PDA medium, all $G$. viride isolates were able to grow at $\mathrm{pH}$ degrees until $\mathrm{pH} 2$, except for 13AJ4 isolate, which was unable to grow at $\mathrm{pH} 2$. The maximum biomass of isolates was at $\mathrm{pH} \mathrm{5}$, except isolate 13AJ4, which occurred at $\mathrm{pH}$ 6. In T. harzianum, almost all isolates were able to grow at $\mathrm{pH} 2$, except for $13 \mathrm{EJ} 8$ isolate, which was unable to grow at $\mathrm{pH} 2$. However, there were 10 isolates (50\% of $T$. harzianum) whose optimum growth was

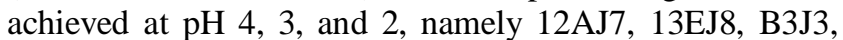
B4J28, C5J10, E4J8, E4J11, E4J13, F1J24, and 13EJ15; while for other isolates, the optimum biomass was reached at $\mathrm{pH} \mathrm{5,6}$ and 7. Moreover, in T. viride, except for B3J19 isolate, wherein maximum biomass was reached at $\mathrm{pH} 2$, all isolates produced the highest mycelium biomass at $\mathrm{pH}$ 5. Variation in growth ability among the isolates in a species living in a specific acidic environment seems to be a common phenomenon, even to the genetic level, as has been reported by Hujslova et al. (2014) and Thanh et al. (2019).

\section{The effect of low pH degrees on the sporulation and germination of conidia}

As much as $84,5 \%$ of the isolates were optimally sporulated at $\mathrm{pH} 3$ and $4(63 \%$ occurred at $\mathrm{pH} 3 ; 21.5 \%$ at pH 4). Only $3.7 \%$ isolates' optimal sporulation occurred at pH 5, 6, and 7. Four isolates were not able to sporulate at 
$\mathrm{pH} 2$, namely $12 \mathrm{AJ} 7,13 \mathrm{AJ} 4, \mathrm{C} 5 \mathrm{~J} 10$, and B3J3. The increase in $\mathrm{pH}$ degrees of the medium caused an increase in sporulation until a certain $\mathrm{pH}$ and then the sporulation decreased with increasing $\mathrm{pH}$ degrees, except for isolates 12AJ7, 13AJ4, C5J10, and F1J4 (Table 4). The same pattern was found in the observation of optimum conidium germination of isolates where as many as $88.9 \%$ of the optimum conidium germination isolates occurred at $\mathrm{pH} 3$ and $4(25.95 \%$ occurred at $\mathrm{pH} 3$ and $62.9 \%$ at $\mathrm{pH} 4)$. $55.6 \%$ isolates were unable to germinate at $\mathrm{pH} 2$ and there were only 2 whose germination reached about $50 \%$ at $\mathrm{pH}$ 2, namely13EJ8 and B3J5. For almost all isolates except F1J24, the percentage of the conidia germination increased with increasing $\mathrm{pH}$ until $\mathrm{pH} 3$ and 4 , then decreased with increasing $\mathrm{pH}$ degrees of the medium. At $\mathrm{pH} 6$, the conidium germination for almost all isolates dropped dramatically to below $10 \%$. At pH 7 , nearly $75 \%$ of isolates were unable to germinate and germination of the $25 \%$ other isolates decreased to below $2 \%$ (Table 5).

There was variation in the ability to produce conidia in $G$. viride, T. harzianum, and $T$. viride from peatlands in West Kalimantan when grown in a medium with a low $\mathrm{pH}$. In the $G$. viride, except for $13 \mathrm{AJ} 4$ isolate where the maximum conidia production occurred at $\mathrm{pH} 5$, all isolates produced maximum conidia at $\mathrm{pH} 4$ and $\mathrm{pH} 3$. In $T$. harzianum, 3 isolates were unable to form conidium at $\mathrm{pH}$ 2, namely $12 \mathrm{AJ} 4, \mathrm{~B} 3 \mathrm{~J} 5$, and F1J4, while other isolates formed conidium but in small amounts. The highest amount of conidia at $\mathrm{pH} 2$ was obtained from 13EJ15 isolate. Most of the isolates produced the maximum number of conidia at $\mathrm{pH} 4$ and $\mathrm{pH} \mathrm{3}$, except for 13AJ6, $\mathrm{C} 5 \mathrm{~J} 12$, and $\mathrm{C} 5 \mathrm{~J} 16$, which produced the maximum number of conidia at $\mathrm{pH} 5$ and $\mathrm{pH}$ 6. Further, 5 isolates could produce the maximum conidium number at $\mathrm{pH} 3$, namely 12AJ4, 13AJ10, B3J9, C5J10, and F1J4. In T. viride, no isolate could sporulate at $\mathrm{pH} 2$ and they produced maximum sporulation at $\mathrm{pH}$ 4. However, there was one isolate that was different from the others because the conidium production was small at all degrees of the given $\mathrm{pH}$ treatment, namely, isolate B4J9. Morphologically, this isolate also tends to show a brighter conidia color, which is yellowish-green. Variation was also found in the ability to germinate conidium of $G$. viride, T. harzianum, and $T$. viride. In $G$. viride, all isolates had optimum conidia germination at $\mathrm{pH} 3$ to 5; however, the conidium could not germinate at $\mathrm{pH} 2$ and $\mathrm{pH} 7$. Variation only occurred at the optimum $\mathrm{pH}$ of conidia germination, where 13EJ4A and F1J6 isolates occurred at $\mathrm{pH} \mathrm{3,} \mathrm{while} \mathrm{13AJ4} \mathrm{and} \mathrm{13EJ4}$ isolates occurred at $\mathrm{pH} 4$.

Variation was also found in the ability to germinate conidium of $G$. viride, $T$. harzianum, and $T$. viride. In the $G$. viride, all isolates had optimum conidium germination at $\mathrm{pH} 3$ to $\mathrm{pH} 5$. However, they were unable to germinate at $\mathrm{pH} 2$ and $\mathrm{pH}$ 7. Notably, a variation only occurred at the optimum $\mathrm{pH}$ degrees of conidium germination where the 13EJ4A and F1J6 isolates occurred at $\mathrm{pH} \mathrm{3,} \mathrm{while} \mathrm{the}$ $13 \mathrm{AJ} 4$ and 13EJ4 isolates occurred at $\mathrm{pH} 4$. The conidium of $10 \mathrm{~T}$. harzianum isolates germinated optimally at $\mathrm{pH} 4$, namely 13EJ15, B3J5, B4J28, C5J10, C5J12, C5J16, C5J18, E4J8, E4J11, and F1J4, while 8 isolates, namely
12AJ4, 12AJ7, 13AJ10, 13AJ6, 13EJ35, B3J3, B3J9, and F1J24, germinated optimally at $\mathrm{pH} 3$. There were only two isolates, 13EJ8 and E4J13, whose optimal conidium germination occurred at $\mathrm{pH} 5$. At $\mathrm{pH} 2$ and $\mathrm{pH} 6$, most isolates were unable to germinate, or even if they were able, the percentage dropped drastically. There were 5 isolates whose conidium were able to germinate at $\mathrm{pH} \mathrm{2,}$ namely 13EJ8, 13EJ15, B3J5, C5J18 and E4J8, whereas others were not able to germinate. There were only 8 isolates that grew at $\mathrm{pH} 6$, namely $13 \mathrm{EJ} 8,13 \mathrm{EJ} 15, \mathrm{~B} 4 \mathrm{~J} 28$, B3J5, B3J9, C5J12, C5J18, and E4J8, while the remaining isolates were unable to grow. All isolates germinated at $\mathrm{pH}$ 7. At $T$. viride, all isolates had optimum conidium germination at $\mathrm{pH} 3$ to $\mathrm{pH} 5$, i.e. B3J19 occurred at $\mathrm{pH} 3$, B4J9 isolate at $\mathrm{pH} \mathrm{4}$, and $\mathrm{B} 4 \mathrm{~J} 20$ isolate at $\mathrm{pH}$ 5. At $\mathrm{pH} 2$ and $\mathrm{pH} 6$, only B3J19 isolate germinated, while at $\mathrm{pH} 7$, all isolates were unable to germinate.

These results are to some extent different from the results of previous studies in which Trichoderma was generally unable to produce spores optimally at $\mathrm{pH}<4$. Onilude and Seyi-Amole (2018) found that optimum sporulation of $T$. harzianum from Nigeria was achieved at $\mathrm{pH} 4$, Trichoderma spp. from Punjab, India, optimum at $\mathrm{pH}$ 6 (Roy et al. 2015), and 4 Trichoderma species from Uttar Pradesh, India, optimum at $\mathrm{pH} 4.6$ to 7.6 (Zehra et al. 2017). The results of this research are also different than the results of Srivastava et al. (2014) and Mishra and Khan (2015) where optimum sporulation $T$. harzianum and $T$. viride (from Kanpur and Bhopal, India) occurred at $\mathrm{pH} 5.5$ 7.5 and 5-9 respectively. These results indicate that the optimum $\mathrm{pH}$ range for conidium sporulation and germination of Trichoderma and Gliocladium is likely to be strongly influenced by the area of origin of the isolate. In this research, the optimum sporulation ability achieved at $\mathrm{pH} 3$ and 4 by most isolates was thought to be the result of adaptation to the peatland environment below $\mathrm{pH} 4$. However, Steyaert et al. (2010) concluded that sporulation at low $\mathrm{pH}$ is also influenced by lighting factors. Fungal biomass was not necessarily correlated with fungal sporulation (Gao 2016). Thus, in low pH level situations, it is necessary to learn more about other environmental factors that influence conidium sporulation and germination in those isolates.

\section{The effect of low pH degrees on the ability as an antagonist against Ganoderma}

Based on Pearson's correlation analysis, it is known that there is no strong correlation between the $\mathrm{pH}$ degrees of peatlands from isolates and the ability of antagonism of each isolate to Ganoderma. The value of $\mathrm{r} 0.36$ ( $p$-value: 0.12 ) at a depth of $0-15 \mathrm{~cm}$ and 0.21 (p-value: 0.37$)$ at a depth of $50-60 \mathrm{~cm}$. It is well known that the ability of Trichoderma spp. and other antagonistic fungi are affected by a certain environmental $\mathrm{pH}$ condition. Therefore, it is important to gather information about the effect of $\mathrm{pH}$ on its growth and antagonistic activity in vitro in the desired environmental $\mathrm{pH}$ situation. In this research, 3 isolate samples were taken randomly to represent $G$. viride (13AJ4 isolate), T. harzianum (13EJ15 isolate) and $T$. viride (B3J19 isolate) species and tested their antagonistic ability 
Table 4. Variation in conidium production of Ganoderma-antagonist isolates from peatlands grown in PDA medium in the $\mathrm{pH}$ range of 2-7 for 7 days

\begin{tabular}{|c|c|c|c|c|c|c|c|}
\hline \multirow{2}{*}{ Isolate } & \multirow{2}{*}{ Species } & \multicolumn{6}{|c|}{ Number of conidium $\left(\times 10^{8} / \mathrm{mL}\right)$} \\
\hline & & pH 2 & pH 3 & pH 4 & pH 5 & pH 6 & pH 7 \\
\hline $12 \mathrm{AJ} 4$ & T. harzianum & $2.99 \mathrm{ab}$ & $16.00 \mathrm{a}$ & 11.30ab & 12.00abcd & $8.75 \mathrm{cdef}$ & $0.41 \mathrm{ab}$ \\
\hline $12 \mathrm{AJ} 7$ & T. harzianum & $0.00 \mathrm{a}$ & $6.61 \mathrm{a}$ & 17.80ab & $6.72 \mathrm{abc}$ & $8.73 \mathrm{cdef}$ & $10.40 \mathrm{cde}$ \\
\hline $13 \mathrm{AJ} 10$ & T. harzianum & $0.02 \mathrm{a}$ & $12.60 \mathrm{a}$ & $2.70 \mathrm{a}$ & $0.05 \mathrm{a}$ & $0.18 \mathrm{a}$ & $0.13 \mathrm{a}$ \\
\hline $13 \mathrm{AJ} 4$ & G. viride & $0.00 \mathrm{a}$ & $5.47 \mathrm{a}$ & $3.35 \mathrm{a}$ & 13.90abcde & 7.59 bcde & 7.45abcd \\
\hline $13 \mathrm{EJ} 4 \mathrm{~A}$ & T. harzianum & $0.60 \mathrm{a}$ & $2.54 \mathrm{a}$ & $9.79 \mathrm{ab}$ & $0.64 \mathrm{ab}$ & $0.21 \mathrm{a}$ & $0.00 \mathrm{a}$ \\
\hline $13 \mathrm{AJ} 6$ & G. viride & $0.09 \mathrm{a}$ & $6.89 \mathrm{a}$ & $6.06 \mathrm{ab}$ & 8.73abcd & $21.11 \mathrm{hij}$ & 6.90abcd \\
\hline $13 \mathrm{EJ} 15$ & T. harzianum & $21.11 \mathrm{~d}$ & $54.80 \mathrm{a}$ & $155.00 \mathrm{def}$ & $14.60 \mathrm{bcde}$ & $13.30 \mathrm{efg}$ & $14.90 \mathrm{def}$ \\
\hline $13 \mathrm{EJ} 35$ & T. harzianum & $0.42 \mathrm{a}$ & $23.00 \mathrm{a}$ & $68.20 b c$ & $16.60 \mathrm{cdef}$ & $7.20 \mathrm{abcde}$ & $20.40 \mathrm{f}$ \\
\hline $13 \mathrm{EJ} 4$ & Gliocladium $s p$. & $21.90 \mathrm{~d}$ & $25.80 \mathrm{a}$ & $31.10 \mathrm{ab}$ & $18.20 \mathrm{cdef}$ & 8.13 bcde & $1.53 \mathrm{abc}$ \\
\hline $13 \mathrm{EJ} 8$ & T. harzianum & $0.01 \mathrm{a}$ & $20.60 \mathrm{a}$ & $181.00 \mathrm{ef}$ & 26.30efg & 14.70efgh & $1.71 \mathrm{abc}$ \\
\hline B3J19 & T. viride & $0.01 \mathrm{a}$ & $74.10 \mathrm{a}$ & $186.00 \mathrm{ef}$ & $186.00 \mathrm{~h}$ & 15.70fghi & $1.99 \mathrm{abc}$ \\
\hline B3J3 & T. harzianum & $0.00 \mathrm{a}$ & $64.50 \mathrm{a}$ & 201.00fg & 19.90cdef & 17.30ghij & $18.30 \mathrm{ef}$ \\
\hline B3J5 & T. harzianum & $12.20 \mathrm{bcd}$ & $26.70 \mathrm{a}$ & $114.00 \mathrm{~cd}$ & $7.89 \mathrm{abc}$ & $1.93 \mathrm{abc}$ & $0.64 a b$ \\
\hline B3J9 & T. harzianum & $0.01 \mathrm{a}$ & $139.00 \mathrm{a}$ & $403.00 \mathrm{i}$ & $22.10 \mathrm{def}$ & $23.60 \mathrm{jkl}$ & $20.60 f$ \\
\hline $\mathrm{B} 4 \mathrm{~J} 20$ & T. viride & $5.92 \mathrm{abc}$ & $131.00 \mathrm{a}$ & $208.00 \mathrm{fg}$ & $5.94 a b c$ & 8.02 bcde & $0.29 \mathrm{ab}$ \\
\hline $\mathrm{B} 4 \mathrm{~J} 28$ & T. harzianum & $0.73 \mathrm{a}$ & $46.50 \mathrm{a}$ & $106.00 \mathrm{~cd}$ & 12.90abcde & $10.30 \mathrm{bcde}$ & $9.45 \mathrm{bcd}$ \\
\hline B4J9 & T. viride & $0.00 \mathrm{a}$ & $1.37 \mathrm{a}$ & $2.46 \mathrm{a}$ & $0.92 \mathrm{ab}$ & $0.24 \mathrm{a}$ & $0.01 \mathrm{a}$ \\
\hline $\mathrm{C} 5 \mathrm{~J} 10$ & T. harzianum & $0.00 \mathrm{a}$ & $35.50 \mathrm{a}$ & $32.90 \mathrm{ab}$ & $18.60 \mathrm{cdef}$ & 29.31 & 18.10ef \\
\hline $\mathrm{C} 5 \mathrm{~J} 12$ & T. harzianum & $1.32 \mathrm{a}$ & $14.90 \mathrm{a}$ & $20.90 \mathrm{ab}$ & $29.00 \mathrm{fg}$ & 10.10defg & $13.80 \mathrm{def}$ \\
\hline $\mathrm{C} 5 \mathrm{~J} 16$ & T. harzianum & $1.82 \mathrm{a}$ & $18.40 \mathrm{a}$ & $23.90 \mathrm{ab}$ & $35.30 \mathrm{~g}$ & $28.30 \mathrm{kl}$ & $18.20 \mathrm{ef}$ \\
\hline C5J18 & T. harzianum & $15.40 \mathrm{~cd}$ & $26.00 \mathrm{a}$ & $31.20 \mathrm{ab}$ & $18.60 \mathrm{cdef}$ & $13.90 \mathrm{efg}$ & $0.53 \mathrm{ab}$ \\
\hline E4J11 & T. harzianum & $1.29 \mathrm{a}$ & $71.40 \mathrm{a}$ & $137.00 \mathrm{de}$ & 12.70abcde & $9.38 \mathrm{def}$ & $1.52 \mathrm{abc}$ \\
\hline E4J13 & T. harzianum & $0.00 \mathrm{a}$ & $104.00 \mathrm{a}$ & $114.00 \mathrm{~cd}$ & $6.71 \mathrm{abc}$ & 4.06abcd & $4.50 \mathrm{abc}$ \\
\hline $\mathrm{E} 4 \mathrm{~J} 8$ & T. harzianum & $0.58 \mathrm{a}$ & $77.80 \mathrm{a}$ & $249.00 \mathrm{~g}$ & $17.30 \mathrm{cdef}$ & $22.30 \mathrm{ijk}$ & $22.00 \mathrm{f}$ \\
\hline $\mathrm{F} 1 \mathrm{~J} 24$ & T. harzianum & $9.58 \mathrm{a}$ & $10.30 \mathrm{a}$ & $16.80 \mathrm{ab}$ & 12.80abcde & $0.89 \mathrm{ab}$ & $0.43 \mathrm{ab}$ \\
\hline F1J4 & T. harzianum & $12.20 \mathrm{bcd}$ & $16.80 \mathrm{a}$ & $7.42 \mathrm{ab}$ & $10.40 \mathrm{abcd}$ & 13.10efg & $0 . a b$ \\
\hline F1J6 & G. viride & $1.25 \mathrm{a}$ & $23.30 \mathrm{a}$ & $16.70 \mathrm{ab}$ & $0.64 \mathrm{ab}$ & $0.25 \mathrm{a}$ & $0.17 \mathrm{a}$ \\
\hline
\end{tabular}

Note: Means followed by the same letters were not significantly different at $5 \%$ level of significance.

Table 5. Variation in the percentage of conidial germination of Ganoderma-antagonist isolates from peatlands in the $\mathrm{pH}$ range 2-7 for 7 days.

\begin{tabular}{|c|c|c|c|c|c|c|c|}
\hline \multirow{2}{*}{ Isolate } & \multirow{2}{*}{ Species } & \multicolumn{6}{|c|}{ Conidial germination (\%) } \\
\hline & & pH 2 & pH 3 & pH 4 & pH 5 & pH 6 & pH 7 \\
\hline $12 \mathrm{AJ} 4$ & T. harzianum & $0.00 \mathrm{a}$ & $76.57 \mathrm{abc}$ & $99.28 \mathrm{f}$ & $81.98 \mathrm{bcd}$ & $0.14 \mathrm{a}$ & $0.00 \mathrm{a}$ \\
\hline $12 \mathrm{AJ} 7$ & T. harzianum & $0.00 \mathrm{a}$ & $97.32 \mathrm{bcd}$ & $96.67 \mathrm{ef}$ & $97.11 \mathrm{~d}$ & $0.88 \mathrm{a}$ & $0.00 \mathrm{a}$ \\
\hline $13 \mathrm{AJ} 10$ & T. harzianum & $0.00 \mathrm{a}$ & $96.64 \mathrm{cde}$ & $97.32 \mathrm{ef}$ & $97.22 \mathrm{~d}$ & $1.92 \mathrm{a}$ & $0.00 \mathrm{a}$ \\
\hline $13 \mathrm{AJ} 4$ & G. viride & $0.00 \mathrm{a}$ & $98.32 \mathrm{de}$ & 90.73 bcde & $79.37 \mathrm{bcd}$ & $2.01 \mathrm{a}$ & $0.00 \mathrm{a}$ \\
\hline $13 \mathrm{EJ} 4 \mathrm{~A}$ & T. harzianum & $0.00 \mathrm{a}$ & 87.60 bcde & $100 f$ & $94.63 d$ & $1.08 \mathrm{a}$ & $0.00 \mathrm{a}$ \\
\hline $13 \mathrm{AJ} 6$ & G. viride & $1.61 \mathrm{a}$ & $95.29 \mathrm{cde}$ & 95.99def & $99.47 \mathrm{~d}$ & $3.63 \mathrm{a}$ & $0.00 \mathrm{a}$ \\
\hline $13 \mathrm{EJ} 15$ & T. harzianum & $2.02 \mathrm{a}$ & 86.00 bcde & $95.86 \mathrm{def}$ & $64.64 b$ & $6.85 \mathrm{a}$ & $0.00 \mathrm{a}$ \\
\hline $13 \mathrm{EJ} 35$ & T. harzianum & $0.000 \mathrm{a}$ & $99.01 \mathrm{e}$ & $96.91 \mathrm{ef}$ & $98.90 \mathrm{~d}$ & $1.01 \mathrm{a}$ & $1.35 \mathrm{a}$ \\
\hline $13 \mathrm{EJ} 4$ & Gliocladium sp. & $3.72 \mathrm{a}$ & $95.15 \mathrm{cde}$ & $97.20 \mathrm{ef}$ & $97.97 \mathrm{~d}$ & $55.81 \mathrm{c}$ & $0.00 \mathrm{a}$ \\
\hline $13 \mathrm{EJ} 8$ & T. harzianum & $48.04 \mathrm{~cd}$ & $61.15 \mathrm{a}$ & $79.17 \mathrm{a}$ & $81.98 \mathrm{bcd}$ & $8.15 \mathrm{a}$ & $0.00 \mathrm{a}$ \\
\hline B3J19 & T. viride & $27.89 b c$ & 95.91cde & $95.33 \mathrm{def}$ & $30.78 \mathrm{a}$ & $2.20 \mathrm{a}$ & $1.23 \mathrm{a}$ \\
\hline B3J3 & T. harzianum & $0.00 \mathrm{a}$ & 98.39de & $97.79 \mathrm{ef}$ & $83.08 \mathrm{bcd}$ & $36.63 b$ & $0.00 \mathrm{a}$ \\
\hline B3J5 & T. harzianum & $54.52 \mathrm{~d}$ & 77.23abcd & $94.84 \mathrm{def}$ & $70.21 b c$ & $6.66 a$ & $0.00 \mathrm{a}$ \\
\hline B3J9 & T. harzianum & $0.00 \mathrm{a}$ & $96.88 \mathrm{cde}$ & $87.10 b c$ & $90.63 \mathrm{~cd}$ & $3.20 \mathrm{a}$ & $0.00 \mathrm{a}$ \\
\hline $\mathrm{B} 4 \mathrm{~J} 20$ & $T$. viride & $0.00 \mathrm{a}$ & $69.54 \mathrm{ab}$ & $85.32 b$ & $84.94 \mathrm{bcd}$ & $0.00 \mathrm{a}$ & $0.00 \mathrm{a}$ \\
\hline B4J28 & T. harzianum & $0.00 \mathrm{a}$ & $100 \mathrm{e}$ & $100 \mathrm{f}$ & $100 \mathrm{~d}$ & $6.38 \mathrm{a}$ & $0.00 \mathrm{a}$ \\
\hline B4J9 & T. viride & $2.78 \mathrm{a}$ & $93.36 \mathrm{cde}$ & $99.42 \mathrm{f}$ & $95.58 \mathrm{~d}$ & $1.56 \mathrm{a}$ & $2.62 b$ \\
\hline C5J10 & T. harzianum & $0.00 \mathrm{a}$ & $76.57 \mathrm{abc}$ & $99.28 \mathrm{f}$ & $81.97 \mathrm{bcd}$ & $0.14 \mathrm{a}$ & $0.00 \mathrm{a}$ \\
\hline C5J12 & T. harzianum & $0.00 \mathrm{a}$ & $94.02 \mathrm{cde}$ & $99.81 \mathrm{f}$ & $98.55 \mathrm{~d}$ & $5.08 \mathrm{a}$ & $0.60 \mathrm{a}$ \\
\hline C5J16 & T. harzianum & $0.29 \mathrm{a}$ & 80.40abcde & $92.54 \mathrm{cdef}$ & $77.61 \mathrm{bcd}$ & $0.98 \mathrm{a}$ & $0.34 \mathrm{a}$ \\
\hline C5J18 & T. harzianum & $13.99 \mathrm{ab}$ & $70.33 \mathrm{ab}$ & $94.89 \mathrm{def}$ & $87.64 \mathrm{bcd}$ & $3.92 \mathrm{a}$ & $0.00 \mathrm{a}$ \\
\hline $\mathrm{E} 4 \mathrm{~J} 11$ & T. harzianum & $0.00 \mathrm{a}$ & $96.93 \mathrm{cde}$ & $100 f$ & $64.81 b$ & $0.00 \mathrm{a}$ & $0.00 \mathrm{a}$ \\
\hline E4J13 & T. harzianum & $0.00 \mathrm{a}$ & $92.93 \mathrm{cde}$ & $95.00 \mathrm{def}$ & $97.32 \mathrm{~d}$ & $1.49 \mathrm{a}$ & $0.00 \mathrm{a}$ \\
\hline E4J8 & T. harzianum & $29.38 b c$ & 89.60 bcde & $95.17 \mathrm{def}$ & $87.03 \mathrm{bcd}$ & $3.80 \mathrm{a}$ & $0.00 \mathrm{a}$ \\
\hline $\mathrm{F} 1 \mathrm{~J} 24$ & T. harzianum & $1.45 \mathrm{a}$ & $95.46 \mathrm{cde}$ & 89.21 bcd & $93.60 \mathrm{~cd}$ & $0.00 \mathrm{a}$ & $0.00 \mathrm{a}$ \\
\hline $\mathrm{F} 1 \mathrm{~J} 4$ & T. harzianum & $0.00 \mathrm{a}$ & $94.66 \mathrm{cde}$ & $100 \mathrm{f}$ & $83.64 \mathrm{bcd}$ & $1.61 \mathrm{a}$ & $0.60 \mathrm{~b}$ \\
\hline F1J6 & G. viride & $0.41 \mathrm{a}$ & 89.25 bcde & $100 f$ & $42.91 \mathrm{a}$ & $1.23 \mathrm{a}$ & $0.18 \mathrm{a}$ \\
\hline
\end{tabular}

Note: Means followed by the same letters were not significantly different at $5 \%$ level of significance 


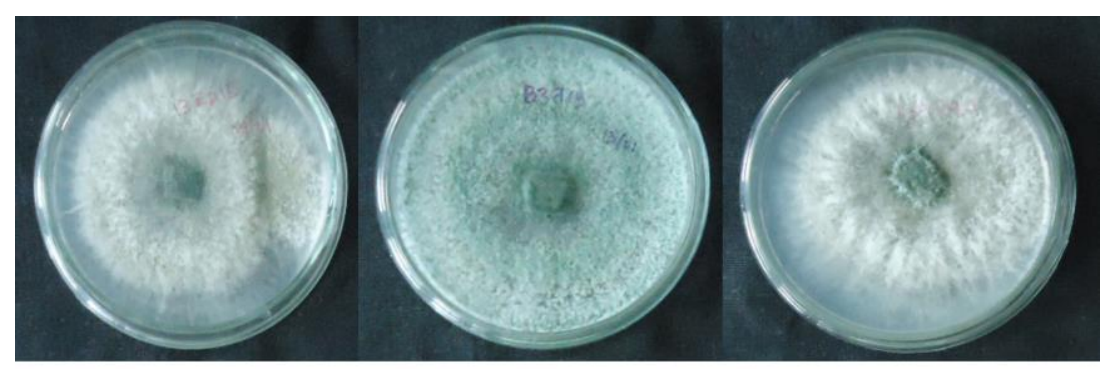

13EJ15

B3J19

13AJ4

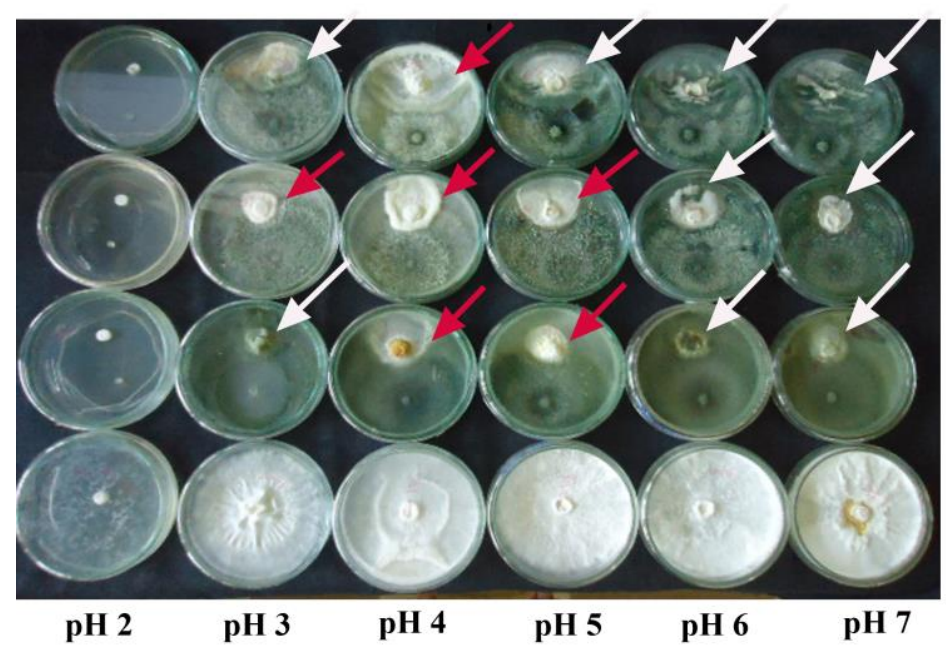

13EJ15

B3J19

13AJ4

G 301

Figure 3. Three examples of antagonistic fungal isolates from peatlands used in the antagonism test (above) and the results of their antagonism test against Ganoderma G301 in the $\mathrm{pH}$ range 2-7 (bottom) on the $7^{\text {th }}$ day after inoculation. The antagonistic fungal mycelium grows past the Ganoderma mycelium (white arrow) and the antagonist mycelium fungus is unable to pass through the Ganoderma mycelium (red arrow)

against Ganoderma on a medium regulated at $\mathrm{pH} 2,3,4,5$, 6 , and 7, each isolate gave a different response. The highest percentage of inhibition against Ganoderma in all isolates occurred at pH 3 and 4. However, all isolates lost their ability at $\mathrm{pH} 2$ because they were unable to grow. At $\mathrm{pH} 2$, Ganoderma was also unable to grow as a result of no interaction. Based on visual observations of colony interactions, the influence of the $\mathrm{pH}$ level of the medium also causes differences in interactions between antagonistic fungi and Ganoderma (Figure 3).

The results of the antagonism observations were different from those of some previous studies. Usually, the ability of the antagonism of Trichoderma spp. was declined at acidic $\mathrm{pH}$. Optimum inhibition of Trichoderma against Fusarium sp., the cause of rot seedling on red onion in Sri Lanka, occurred at $\mathrm{pH} 6$ (Abeyratne and Deshappriya 2018). Also, inhibition of $T$. viride against Sclerotium rolfsii and Rhizoctonia solani occurred at $\mathrm{pH} 5.5$ to $\mathrm{pH} 6$ (Bagwan 2010). Media pH degrees affect the ability of fungal antagonism possibly through its influence in regulating enzyme secretion and its stability. Regulating the secretion of these enzymes plays an important role when fungal acting as a competitor for nutrition and living space as well as a mycoparasites. The $\beta$-glucosidase enzyme was activated below $\mathrm{pH} 5$, while xylosidase was activated at pH 6 (Naher et al. 2014). Asran-Amal et al.
(2010) also identify $\mathrm{pH}$ 6-7 as the optimal $\mathrm{pH}$ range for the activity of chitinase enzymes released by Trichoderma sp. Therefore, further research is needed to determine the effect of low $\mathrm{pH}$ degrees on the mechanism of the antagonism more clearly.

Observation of mycelium biomass and colony diameter showed that most of the Ganoderma-antagonist fungal isolates from West Kalimantan peatlands were able to grow at acidic $\mathrm{pH}(\mathrm{pH} \mathrm{4,3}$, and 2). This ability was alleged to be the result of a process of natural selection in the peatlands environment, which occurs continuously such that genetic variation is enabled. Some previous research results indicate that based on the dry weight of the biomass, Trichoderma species have a variation in optimum $\mathrm{pH}$ range, depending on the native habitat of the isolates. These variations of optimum $\mathrm{pH}$ were from a $\mathrm{pH}$ range of 4.6 to 6.8 (Jackson et al. 1991), between 5.5 to 7.5 (Singh et al. 2014), or 3.5 to 5 (Onilude and Seyi-Amole 2018). Taylor et al. (2017) stated that fungal genomes are remarkably fluid and variable. Variation in wild populations is a rich resource for associating genetic variation with phenotypic variation. The sources of genetic variation, including single nucleotide mutations and recombination, gene gain and loss, gene family expansion and contraction, horizontal gene transfer, loss of heterozygosity, genome rearrangements, epigenetic 
modifications, and other sources. Genetic variation in the fungal population could potentially lead to differences in physiology function and response to the environments (Lind et al. 2017; Longnya et al. 2020). In general, genetic variation in the fungal population was the result of longterm adaptations to their ecological environments and environmental heterogeneity has played an important role in these processes (Xu et al. 2014). The variations in the peatland environments, especially those related to $\mathrm{pH}$ and other chemical environmental characteristics were believed to trigger these genetic variations. However, soil age and the $\mathrm{C}$ accumulation rate were found to play important roles in shaping the fungal community structure (Zhang et al. 2017). Also, in West Kalimantan peatlands, changes in water content, bulk density and porosity of the soil were positively correlated with the fungal communities in peatlands (Nusantara and Aspan 2017). Therefore, physical characteristics of peat such as bulk density, soil temperature, water table depth, water content, and soil porosity were also believed to play an important role in the occurrence of fungal genetic variation.

Based on these results, most of the isolates tested in this research were believed to be acid-tolerant fungi, as proposed by Gross and Robbins (2000) and Hujslova et al. (2014). These fungi, in addition to being able to grow in acidic environments, were also still able to grow in an environment that tends to be neutral. This shows that most of the antagonistic fungi isolates from the peatland were indigenous peat fungi that were in accordance with the conditions of a low $\mathrm{pH}$ level so that their activities were not disturbed by low $\mathrm{pH}$ degrees.

The results of this research confirm previous studies about the presence of acid-tolerant fungi (Gross and Robbins 2000; Hujslova et al. 2014; Mardanov et al. 2016; Thanh et al. 2019). For example, the study of Mardanov et al. (2016), in which strains of Penicillium were taken from wastes of the ore mining deposit in Siberia that were known to be able to grow in a $\mathrm{pH} 1.9$, and 4 acid-tolerant Trichoderma species reported by Gross and Robbins (2000), which have the optimum growth $\mathrm{pH}$ range varies from 3.7 to $4.7,2$ to $7,3.4$ to 4.7 and 3.1 to 5 . The results of this research also indicate that most of the fungal isolates from peatlands could act as biological control agents against Ganoderma on peatlands because they could grow at $\mathrm{pH} 3$ to 4 , which is the $\mathrm{pH}$ of the peatlands environment in this research site. Most of the isolates were able to grow and produce abundant conidium and their conidia were able to germinate normally at the same $\mathrm{pH}$ degrees and were able to act as an antagonist for the pathogenic fungi Ganoderma that is devastating to oil palm plantations in peatlands.

\section{ACKNOWLEDGEMENTS}

The author would like to thank the Directorate General of Research and Development, Ministry of Research and Higher Education, Indonesia for providing funding for this research according to contract No. 107/ADD/SP2H/LT/DRPM/VIII/2017.

\section{REFERENCES}

Abeyratne GDD, Deshappriya N. 2018. The effect of pH on the biological control activities of a Trichoderma sp. against Fusarium sp. isolated from the commercial onion fields in Sri Lanka. Trop Plant Res 5 (2): 121-128.

Ahlem H, Mohammed E, Badoc A, Ahmed L. 2012. Effect of pH, temperature and water activity on the inhibition of Botrytis cinerea by Bacillus amyloliquefaciens isolates. Afr J Biotechnol 11 (9): 22102217.

Alexander A, Abdullah S, Rossall S, Chong KP. 2017. Evaluation of the efficacy and mode of action of biological control for suppression of Ganoderma boninense in oil palm. Pak J Bot 49 (3): 1193-1199.

Andriesse JP. 1988. Nature and Management of Tropical Peat Soils. Food and Agriculture Organization of the United Nations, Roma. http://www.fao.org/3/x5872e/x5872e06.htm\#4.3.3\%20Acidity.

Asran-Amala, A, S.M. Moustafa-Mahmoud, K.K. Sabet, O.H. El Banna. 2010. In vitro antagonism of cotton seedlings fungi and characterization of chitinase isozyme activities in Trichoderma harzianum. Saudi J Biol Sci 17: 153-157.

Assis K, Chong KP, Idris AS, Ho CM. 2016. Economic loss due to Ganoderma disease in oil palm. In: Proceeding of Indonesia Conference on Mathematics, Statistics and Scientific Computing, Kuala Lumpur, 11-12 February 2016.

Azahar TM, Jawahir CM, Mazliham S, Boursier P. 2011. Temporal analysis of basal stem rot disease in oil palm plantations: an analysis on peat soil. IJET-IJENS 11 (03): 96-101.

Bagwan NG, 2010. Influence of temperature and $\mathrm{pH}$ on antagonistic potential of Trichoderma viride in vitro. Intl J Plant Protec 3 (2): 165169.

Bakker MG, Manter DK, Sheflin AM, Weir TL, Vivanc JM. 2012. Harnessing the rhizosphere microbiome through plant breeding and agricultural management. Plant Soil 360: 1-13.

Cánovas D, Studt L, Marcos AT, Strauss J. 2017. High-throughput format for the phenotyping of fungi on solid substrates. Sci Rep 7: 4289. DOI: $10.1038 / \mathrm{s} 41598-017-03598-9$

Chong KP, Dayou J, Alexander A. 2017. Detection and Control of Ganoderma boninense in Oil Palm Crop. Springer, Switzerland.

Cooper RMA, Flood JB, Rees RW. 2011. Ganoderma boninense in oil palm plantations: current thinking on epidemiology, resistance and pathology. The Planter 87 (1024): 515-526.

Darmono TW. 2000. Ganoderma in oil palm in Indonesia: Current status and prospective use of antibodies for the detection of infection. In: Flood J, Bridge PD, Holderness M (eds.). Ganoderma diseases of perennial crops. CABI Publishing, New York.

Direktorat Jenderal Perkebunan, 2017. Statistik Perkebunan Indonesia 2016-2018, Direktorat Jenderal Perkebunan, Jakarta. [Indonesian]

Domsch KH, Gams W. 1972. Compendium of Soil Fungi, Volume I. Academic Press, London.

Fee CG. 2011. Management of Ganoderma diseases in oil palm plantations. The Planter 87 (1022): 325-339.

Gao L. 2016. An improved method to optimize the culture conditions for biomass and sporulation of mycoparasitic fungus Trichoderma viride TV-1. J Yeast Fungal Res 7 (1): 1-6. DOI: 10.5897/JYFR2015.0162

Gomes E, Da Silva R, Pereira JC, Ladino-Orjuela G. 2018. Fungal growth on solid substrates: a physiological overview. In: Pandey A, Larroche C, Soccol CR (eds.). Current Developments in Biotechnology and Bioengineering, Elsevier, Amsterdam.

Gross IS, Robbins IE, 2001. Acidophilic and acid-tolerant fungi and yeasts. Hydrobiologia 433: 91-109.

Hujslova M, Kubatova A, Kostovcik M, Blanchette RA, de Beer ZW, Chudíckova M, Kolarik M. 2014. Three new genera of fungi from extremely acidic soils. Mycol Progress 13: 819-831.

Jackson AM, Whipps JM, Lynch JM. 1991. Effects of temperature, pH and water potential on growth of four fungi with disease biocontrol potential. World J Microb Biot 7: 494-501.

Lind AL, Wisecaver JH, Lameiras C, Wiemann P, Palmer JM, Keller NP, Rodrigues F, Goldman GH, Rokas A. 2017. Drivers of genetic diversity in secondary metabolic gene clusters within a fungal species. Plos Biol 15 (11): e2003583. DOI: 10.1371/journal. pbio.2003583.

Longya A, Talumphai S, Jantasuriyarat C. 2020. Morphological characterization and genetic diversity of rice blast fungus, Pyricularia oryzae, from Thailand using ISSR and SRAP markers. J Fungi 6: 38. DOI:10.3390/jof6010038 
Mardanov AV, Glukhova LB, Gruzdev EV, Beletsky AV, Karnachuk OV Ravin NV. 2016. The complete mitochondrial genome of the acidtolerant fungus Penicillium ShG4C. Genom Data 10: 141-14.

McIlvaine TC. 1921. A buffer solution for colorimetric comparison. J Biol Chem 49: 183-186.

Miettinen J, Shi C, Liewolerant SC. 2016. Land cover distribution in the peatlands of Peninsular Malaysia, Sumatra and Borneo in 2015 with changes since 1990. Glob Ecol Conserv 6: 67-78

Mishra PK, Khan FN. 2015. Effect of different growth media and physical factors on biomass production of Trichoderma viride. People's J Sci Res 8 (2): 11-16.

Muniroh MS, Nusaibah SA, Vadamalai G, Siddique Y. 2019. Proficiency of biocontrol agents as plant growth promoters and hydrolytic enzyme producers in Ganoderma boninense infected oil palm seedlings. Curr Plant Biol 20: 100116. DOI: 10.1016/j.cpb.2019.100116.

Musa H, Nusaibah SA, Khairulmazmi A. 2018. Assessment on Trichoderma spp. mixture as a potential biocontrol agent of Ganoderma boninense infected oil palm seedlings. J Oil Palm Res 30 (3): 403-415.

Naher L, Siddiquee S, Yusuf UK, Mondal MMA. 2015. Issues of Ganoderma spp. and basal stem rot disease management in oil palm. Am J Agric Sci 2 (3): 103-107.

Naher L, Yusuf UK, Ismail A, Hossain K. 2014. Trichoderma spp.: A biocontrol agent for sustainable management of plant diseases. Pak J Bot 46 (4): 1489-1493.

Notohadiprawiro RMT, 1985. Selidik cepat ciri tanah di lapangan. Ghalia Indonesia, Jakarta. [Indonesian]

Nusantara RW, Aspan A. 2017. Differentiation of soil organisms at different types of peatland in West Kalimantan, Indonesia. Bonorowo Wetlands 7 (1): 26-30.

Onilude AA, Seyi-Amole DO. 2018. Mycelia growth and spore yield of Trichoderma harzianumin batch and fed-batch cultures: Influence of pH and temperature. Intl J Curr Microbiol App Sci 7 (4): 627-635. DOI: $10.20546 /$ ijcmas.2018.704.070

Pilotti CA, 2005. Stem rots of oil palm caused by Ganoderma boninense: Pathogen biology and epidemiology. Mycopathologia 159: 129-137.

Priwiratama H, Prasetyo AE, Susanto A. 2014. Pengendalian Penyakit Busuk Pangkal Batang Kelapa Sawit secara Kultur Teknis. J Fitopatol Indones 10 (1): 1-7. DOI: 10.14692/jfi.10.1.1 [Indonesian]

Rakib RM, Bong CJ, Khairulmazmi A, Idris AS, Jalloh MB, Ahmed OH. 2017. Association of copper and zinc levels in oil palm (Elaeis guineensis) to the spatial distribution of Ganoderma species in the plantations on peat. J Phytopathol 165: 276-282.

Rakib RM, Bong CJ, Khairulmazmi A, Idris AS, Jalloh MB, Idris AS. 2014. Occurrence and spatial distribution of Ganoderma species causing upper and basal stem rot in oil palm. J Food Agric Environ 12 (2): 360-364

Roy MK, Hembram S, Debnath A. 2015. Effect of different media and $\mathrm{Ph}$ on growth and sporulation of different native Trichoderma spp. The Bioscan 10 (4): 1833-1837.

Senthamizhlselvan P, Alice J, Sujeetha RP, Jeyalakshmi C. 2010. Growth, sporulation and biomass production of native entomopathogenic fungal isolates on a suitable medium. J Biopesticides 3 (2): 466-469.
Singh A, Shahid M, Srivastava M, Pandey S, Sharma A, Kumar V. 2014 Optimal physical parameters for growth of Trichoderma species at varying $\mathrm{pH}$, temperature and agitation. Virol Mycol 3: 127.

Srivastava M, Singh V, Shahid M, Singh A, Kumar V. 2014. Determination of biochemical and physiological aspects of a biocontrol agent Trichoderma harzianum Th azad. Intl J Adv Res 2 (3): 841-849.

Steyaert JM, Weld RJ, Stewart A. 2010. Ambient pH intrinsically influences Trichoderma conidiation and colony morphology. Fungal Biol-UK 114: 198-208.

Supriyanto, Purwanto, Poromarto SH, Supyani. 2020. The relationship of some characteristics of peat with oil palm basal stem rot (BSR) caused by Ganoderma in peatlands. In: Proceeding The 4th International Conference on Climate Change: "Climate Change: The Risk to Sustainable and Environmental Issue”. Yogyakarta, Indonesia, 18-19 November 2019

Susanto A, Rahmadi HY, Priwiratama H, Yenni Y, Suprianto E, Purba AR. 2011. Seleksi ketahanan berbagai persilangan kelapa sawit terhadap Ganoderma boninense. Jurnal Penelitian Kelapa Sawit 19 (1): 43-53. [Indonesian]

Taylor JW, Branco S, Gao C, Hann-Soden C, Montoya L, Sylvain I, Gladieux P. 2017. Sources of fungal genetic variation and associating it with phenotypic diversity. Microbiol Spectrum 5 (5): FUNK-00572016. DOI: 10.1128/microbiolspec.FUNK-0057-2016

Thanh VN, Thuy NT, Huong HTT, Hien DD, Hang DTM, Anh DTK, Hüttner S, Larsbrink J, Olsson L. 2019. Surveying of acid-tolerant thermophilic lignocellulolytic fungi in Vietnam reveals surprisingly high genetic diversity. Sci Rep 9: 3674. DOI: : 10.1038/s41598-01940213-5

Ting ASY, Jioe E. 2016. In vitro assessment of antifungal activities of antagonistic fungi towards pathogenic Ganoderma boninense under metal stress. Biol Control 96: 57-63.

Veiter L, Rajamanickam V, Herwig C. 2018. The filamentous fungal pellet-relationship between morphology and productivity. Appl Microbiol Biotechnol 102: 2997-3006.

Wong LC, Bong CFJ, Idris AS. 2012. Ganoderma species associated with basal stem rot disease of oil palm. Am J Applied Sci 9 (6): 879-885.

Xu L, Lu Y, You Q, Liu XL, Grisham MP, Pan YB, Que YX. 2014. Biogeographical variation and population genetic structure of Sporisorium scitamineum in Mainland China: Insights from ISSR and SP-SRAP markers. Sci World J 2014: 296020. DOI: $10.1155 / 2014 / 296020$

Zehra A, Dubey MK, Meena M, Upadhyay RS. 2017. Effect of different environmental conditions on growth and sporulation of some Trichoderma species. J Environ Biol 38: 197-203.

Zhang Z, Zhou X, Tian L, Ma L, Luo S, Zhang J, Li XJ, Tian CJ. 2017. Fungal communities in ancient peatlands developed from different periods in the Sanjiang Plain, China. PLoS One 12 (12): e0187575. DOI: 10.1371/journal.pone.0187575

Zhou Y, Han LR, He HW, Sang B, Yu DL, Feng JT, Zhang X. 2018. Effects of agitation, aeration and temperature on production of a novel glycoprotein GP-1 by Streptomyces kanasenisi ZX01 and Scale-up based on volumetric oxygen transfer coefficient. Molecules 23: 125. DOI:10.3390/molecules23010125. 